\title{
Komparace výsledků přijímacích zkoušek z gymnastických disciplín pro akademické roky 2010/2011 a 2011/2012
}

\section{Comparison of the results of entrance examination from discipline of gymnastics for academic years 2010/2011 a 2011/2012}

\author{
Pavlína Vaculíková, Alena Skotáková, Lenka Svobodová, \\ Martin Sebera, Dagmar Šimberová \\ Fakulta sportovních studií, Masarykova univerzita, Brno
}

\begin{abstract}
Abstrakt
Discipliny sportovni gymnastiky jsou nedilnou součástí prijímacího řizeni na vysoké školy s tělovýchovným zaměrením již řadu let. Nejinak je tomu také na Fakultě sportovních studii Masarykovy univerzity v Brně. Ve snaze co možná nejlépe postihnout úroveň motorických schopností a určitých pohybových predpokladů potřebných pro studium praktických předmètù s gymnastickým zaměřením a nutno dodat, že v posledních letech také v souladu s hledisky ekonomickými, neustále docházi k hledáni nejvhodnější volby nářadi a také obsahu. Právě z těchto důvodů došlo v prijímacím ř́zení pro akademický rok 2011/2012 ke změnám, a to jak v jedné $z$ disciplin, tak také v obsahu discipliny druhé. Největši zménou bylo nahrazeni hrazdy dosažné u žen a hrazdy doskočné u mužů hrazdou závěsnou. Výběrem cviků jsme se snažili postihnout v co největši míre úroveň vybraných motorických schopností (v prípadè závěsné hrazdy především schopností silových), která by se mohla odrazit ve snazším zvládnutí nových pohybových dovedností při výuce gymnastiky během studia. Sestava na akrobacii byla rozšířena o zpevňovací cvičení, která měla za cíl ukázat schopnost uchazečù vědomè ovládat tělo jako celek.

Sledovaný soubor tvořilo celkem 1037 - 509 uchazečù pro rok 2010/2011 (132 žen a 377 mužů) a 529 uchazeču (140 žen a 389 mužů) pro rok 2011/2012. V našem př́spěvku jsme sledovali rozdil v hodnocení jednotlivých disciplín u mužů i žen v přijímacím řizení pro akademický rok 2010/2011 a 2011/2012. Dalším cílem komparace a zjištěni vzájemného vztahu mezi jednotlivými disciplínami byla jejich možná zaměnitelnost v prijímacím ř́zení pro akademický rok 2012/2013. Z výsledki̊ je patrný výrazný rozdíl mezi hodnocením mužu a žen při hodnoceni na hrazdě a to v roce 2010/2011 i v roce 2011/2012. Naopak ženy v obou letech dosáhly lepšich výsledků při cvičení na akrobacii. Co se týče zaměnitelnosti jednotlivých disciplín, korelační koeficienty poukazují na možnou zaměnitelnost hrazdy za akrobacii nebo akrobacie za hrazdu.
\end{abstract}

\section{Abstract}

The disciplines of gymnastics have been an important part of entrance examination at the university with the physical orientation already for many years. It is also the same case at the faculty of physical studies at Masaryk University in Brno. Because there is a need to give a true picture of the level of motoric abilities and certain motion presumptions which are needed for studies of practical subjects with using gymnastics, there is more and more need to find the best choice of gymnastics equipment and also its content. It is also because of economical reasons. This was the reason why there were some changes in entrance examinations in academic year 2010/2011 and 2011/2012. It was done in one of disciplines but also in the content of the second discipline. The biggest change concerned the horizontal bar for women and men to trapeze bar. Choosing of exercises we tried to cover as much as possible the level of chosen motoric abilities (in case of trapeze bar foremost the force abilities), which could be helpful for easier managing new locomotive skills during gymnastics lessons. The exercises on the floor were spread in strengthening exercises whose aim was to show abilities of the applicants how to control the body as the complex. The monitoring unit was created in total 1037-509 for 2010/2011 (132 women and 377 men) and 529 applicants (140 women and 389 men) for 2011/2012. In our contribution we tried to watch the differences in evaluation of individual disciplines for men and women in entrance examination 
for academic year 2010/2011 and 2011/2012. Next aim of comparison and findings of mutual relationship between each discipline was their possible exchangeability in entrance examination for academic year 2012/2013. There is visible difference between evaluation of men and women on trapeze bar and it was in 2010/2011 and 2011/2012. On the contrary women got better results on the floor in both years. As far as the exchangeability of individual disciplines is concerned, correlation coefficients show possible exchangeability trapeze for floor or floor for trapeze.

Klíčová slova: prijímací zkoušky, gymnastika, hrazda, akrobacie

Keywords: entry exam, gymnastics, bar, floor

\section{Úvod}

Většina, ne-li všichni autoři zabývající se problematikou sportovní gymnastiky se shodují na skutečnosti, že gymnastika je velice náročným a komplexním sportovním odvětvím. Pro zvládnutí jednotlivých disciplín je nutná vysoká úroveň všech motorických schopností.

Jalovecká (2010) uvádí, že sportovní gymnastika patří mezi esteticko-koordinační sporty, které kladou velké nároky na sportovní činnost jedince. Existuje mnoho variant gymnastiky, které umožňují procvičení těla na všech úrovních od vrcholové po rekreační - sportovní gymnastika, všeobecná gymnastika, zdravotní gymnastika, rytmická atd.

Mračková (2011) cituje studie Vaňka (1984) a Havlíčkové (2006), kteří sportovní gymnastiku řadí mezi individuální sporty, ve kterých se klade velký důraz na prožívání, vnímání pohybových činností a jejich vzájemné koordinaci. Každé provedení pohybu musí mít estetický výraz, proto se řadí sportovní gymnastika mezi esteticko-koordinační sporty, ve kterých je nezbytný smysl pro rytmus, rovnováhu, orientaci v prostoru a čase, dále je nutná vysoká úroveň flexibility a výborná svalová koordinace.

Hedbávný (2011) popisuje, že z hlediska motorických předpokladů k vysoké výkonnosti je ve sportovní gymnastice považována za nejdůležitější úroveň koordinačních a silových schopností, doplněná o specifické vytrvalostní a rychlostní schopnosti. Z koordinačních schopností determinují výkon ve sportovní gymnastice schopnost orientační, kinesteticko-diferenciační, rovnováhová, rytmická a v neposlední řadě flexibilita. Ze silových schopností je to síla explozivní, izometrická a částečně vytrvalostní. Gymnastická cvičení jsou charakteristická střídáním statické a dynamické svalové zátěže.

Kubička (1993) popisuje, že složitost motoriky v gymnastice je charakteristická zpevněným držením těla, lokomocí horních i dolních končetin, využíváním jak izometrického, tak izotonického režimu práce, cvičením na všech úrovních (sedy, lehy, visy, vzpory) apod. Tato gymnastická motorika klade zvýšené nároky na přesné zvládnutí pohybových struktur s dominantním zaměřením na jejich výraz. Gymnastické prvky se spojují do větších pohybových celků, tzv. sestav, které jsou finální stránkou gymnastického projevu. Nezměrné množství těchto pohybových úkonů, které musí gymnasté vykonávat na nářadí, vyžaduje dlouhou dobu učení (Kubička, 1993, Vaněk, 1984). Gymnastické výkony, ve kterých se objevují různé švihové, silové statické a vedené prvky na koberci či na náradích, se hodnotí kvalitativně podle daných pravidel a posuzovacích stupnic. „Celková hodnota gymnastické sestavy je tvořena hodnotou obsahovou, technickou a estetickou“ (Kubička, 1993, str. 25). Bodové ohodnocení výkonu se vztahuje jak k obtížnosti předváděného obsahu, tak ke způsobu provedení se zřetelem na technická a estetická kritéria. Technická kritéria se vztahují především k mechanickému způsobu řěsení pohybového úkolu, k rozsahu pohybu a pohybového rytmu ve smyslu koordinace jednotlivých prvků. Estetická kritéria se vztahují k choreografii, k pohybovému výrazu a stylu, k dokonalosti tvaru pohybu a ke specifické gymnastické motorice (Kubička, 1993).

V posledních letech popularita gymnastiky ve světě roste, dochází k infiltraci gymnastických cvičení a gymnastických dovedností do ostatních sportovních činností, jako je např. tanec, lyžování, úpolové sporty atd. Gymnastika jako soubor cvičení všestranně rozvíjí takřka všechny pohybové schopnosti. Největší vliv mají gymnastická cvičení na rozvoj koordinace, zejména její obratnostní složky, a tím posilují schopnost se rychle a trvale učit novým pohybovým dovednostem. Z tohoto hlediska je gymnastická průprava významným pomocníkem růstu výkonnosti ve většině sportovních odvětví a je nedílnou součástí výuky tělesné výchovy na základních a středních školách (Vaculíková a kol., 2011). 


\section{Výzkumný cíl}

Cílem našeho př́spěvku je komparace hodnocení gymnastických disciplín (závěsná hrazda X hrazda, akrobacie) v přijímacím řízení v akademických letech 2010/2011 a 2011/2012 po změně obsahu jednotlivých disciplín.

Dalším cílem příspěvku bylo zjištění vztahu v hodnocení jednotlivých disciplín a jejich možné zaměnitelnosti v dalším přijímacím řízení.

\section{Metody}

Pro akademický rok 2010/2011 přijímací zkoušky ze sportovní gymnastiky obsahovaly sestavu na hrazdě a na akrobacii. Muži cvičili na hrazdě doskočné a ženy na hrazdě dosažné.

V akademickém roce 2011/2012 sestávaly přijímací zkoušky ze cvičení na závěsné hrazdě a akrobacii.

V obou letech se hodnotila technika provedení jednotlivých cviků, gymnastické držení těla, doskok. Hodnocení se pohybovalo na škále od 0 do 10 bodů, kdy zisk 10 bodů je nejvyšším možným bodovým hodnocením. Za odchylky od technicky správného provedení cviku bylo strhnuto 0,5 bodu. Za neprovedený cvik nebo poskytnutou dopomoc se srážela celá hodnota cviku. Pohyby a polohy paží na akrobacii bylo možné dotvořit libovolně.

Posuzovateli v obou letech byli titíž pedagogové (u každé disciplíny 2 pedagogové) Fakulty sportovních studií, kteří se specializují na výuku gymnastických disciplín (s praxí v pozicích trenérů i rozhodčích). Ve snaze o co nejvyšší míru objektivity při hodnocení disciplín, proběhlo interní školení, na kterém byly podrobněji rozebrány bodové srážky za provedení jednotlivých pohybových tvarů.

Během provádění sestavy hodnotitelé zapisovali do záznamových archů nejen celkové bodové hodnocení celého výkonu, ale také získané body za jednotlivé (provedené i neprovedené) cvičební tvary.

\section{Charakteristika výzkumného souboru}

Přijímacích zkoušek z gymnastiky (uchazeči o směry Tělesná výchova a sport, Animátor sportovních aktivit) se pro akademický rok 2010/2011 zúčastnilo celkem 509 uchazečů (132 žen a 377 mužů). V roce 2011/2012 to bylo celkem 529 uchazečů (140 žen a 389 mužů).

\section{Zpracování}

K zaznamenání a statistickému zpracování naměřených hodnot jsme využili programu Microsoft Office Excel 2003.

Pro analýzu dat jednotlivých gymnastických disciplín jsme zvolili základní statistické charakteristiky, jakými jsou aritmetický průměr a směrodatná odchylka a dále pro zjištění rozdílů mezi skupinami t-test společně s výpočtem Cohenova d (Cohen, 1994). Hladinu statistické významnosti jsme stanovili 0,05

K porovnání závislosti dvou disciplín (hrazda X akrobacie, závěsná hrazda X akrobacie) jsme použili koeficient korelace.

\section{Výsledky}

Výsledky hodnocení jednotlivých disciplín mužů a žen v přijímacím řízení pro roky 2010/2011 a 2011/2012 uvádíme v tabulkách $1-4$.

Tab. 1 Výsledky hodnocení hrazda-ženy

\begin{tabular}{|ccccccc|}
\hline & N & PRŮMĚR & STD. ODCHYLKA & t-value & p & Cohen d \\
\hline $2010 / 2011$ & 132 & 5,24 & 3,18 & $-2,28$ & 0,023 & 0,28 \\
$2011 / 2012$ & 140 & 6,05 & 2,70 & & & \\
& & & & & & \\
\hline
\end{tabular}

Z tabulky 1 je patrné, že změna v hodnocení je statisticky významná. Żeny v roce 2011 při cvičení na závěsné hrazdě dosáhly zlepšení o 0,81 bodu. Nepatrně se také snížila hodnota směrodatné odchylky. Cohenův koeficient d naznačuje, že rozdíl je sice malý, ale znatelný. 
Tab. 2 Výsledky hodnocení hrazda-muži

\begin{tabular}{|ccccccc|}
\hline & N & PRŮMĚR SM. ODCHYLKA & t-value & p & Cohen d \\
\hline $2010 / 2011$ & 377 & 6,39 & 2,92 & $-6,69$ & 0,00 & 0,48 \\
$2011 / 2012$ & 389 & 7,55 & 1,76 & & & \\
& & & & & & \\
\hline
\end{tabular}

Tabulka 2 ukazuje na statisticky významnou změnu v hodnocení mužů při cvičení na hrazdě. Muži v přijímacím řízení pro rok 2011/2012 dosáhli lepšího výsledku o 1,16 bodu než v přijímacím řízení pro rok 2010/2011. Současně klesla hodnota směrodatné odchylky, což poukazuje na větší homogenitu mužských uchazečů v této disciplíně v roce 2011/2012. Cohenův koeficient značí, že rozdíl je již výrazný nejen statisticky, ale i věcně.

Tab. 3 Výsledky hodnocení akrobacie - ženy

\begin{tabular}{|ccccccc|}
\hline & N & PRŮMĚR & STD. ODCHYLKA & t-value & p & Cohen d \\
\hline $2010 / 2011$ & 132 & 6,06 & 2,11 & 1,21 & 0,22 & 0,07 \\
$2011 / 2012$ & 140 & 5,78 & 2,27 & & & \\
\hline
\end{tabular}

Z tabulky 3 můžeme vyčíst, že si ženy v přijímacím řízení pro rok 2011/2012 pohoršily o 0,32 bodu. Tato změna není statisticky, ani věcně významná.

Tab. 4 Výsledky hodnocení akrobacie - muži

\begin{tabular}{|ccccccc|}
\hline & N & PRŮMĚR & STD. ODCHYLKA & t-value & p & Cohen d \\
\hline $2010 / 2011$ & 132 & 6,06 & 2,11 & 1,21 & 0,22 & 0,07 \\
$2011 / 2012$ & 140 & 5,78 & 2,27 & & & \\
\hline
\end{tabular}

Tabulka 4 ukazuje na zhoršení výsledků mužů při cvičení na akrobacii v přijímacím řízení pro rok 2011/2012 o 1,07 bodu. Tato změna je statisticky významná, včetně věcné významnosti (Cohenovo d), který naznačuje, že lze konstatovat výrazné zhoršení

\section{Interpretace výsledků}

\section{komparace výsledků hrazda - ženy 2010/2011 a 2011/2012}

V přijímacím řízení pro akademický rok 2010/2011 ženy cvičily na hrazdě dosažné. V přijímacím řízení pro rok 2011/2012 došlo ke změně a hrazda dosažná byla nahrazena hrazdou závěsnou. Z výsledku vidíme, že v přijímacím řízení 2011/2012 došlo ke statisticky významnému bodovému nárůstu. Tato skutečnost může být způsobena koordinačně a také technicky méně náročnou sestavou na závěsné hrazdě. Roli může hrát také fakt, že závěsná hrazda je snáze dostupná a k nácviku sestavy uchazeči nepotřebují takřka žádné metodické nebo didaktické vedení

\section{komparace výsledků hrazda - muži 2010/2011 a 2011/2012}

Stejně jako u žen, také u mužů došlo ke statisticky významnému zvýšení bodového hodnocení v této disciplíně. Důvody tohoto zlepšení mohou být shodné jako důvody zlepšení žen. U mužů nesmíme opominout také mnohem vyšší geneticky podmíněnou úroveň silových schopností, at' statických nebo dynamických než u žen. Současně předpokládáme, že muži jsou častějšími návštěvníky fitcenter, kde závěsná hrazda je nedílnou součástí vybavenosti. Z těchto důvodů by pro nás nemusel být tak výrazný bodový nárůst překvapením. Zajímavé je sledovat vývoj směrodatné odchylky. V přijímacím řízení pro rok 2011/2012 hodnota směrodatné odchylky výrazně klesla, což znamená mnohem větší homogenitu souboru. Důvodem může být právě vynechání 
koordinačně a technicky náročných cviků, které se objevovaly na hrazdě doskočné (výmyk, toč a podmet). Tyto cviky kladly vysoké nároky na uchazeče nejen po stránce rozvoje úrovně koordinačních schopností, ale také po stránce zabezpečení tělocvičny s požadovaným vybavením a v neposlední řadě zapojení osoby schopné metodicky vést a dát dopomoc a záchranu.

\section{komparace výsledků akrobacie - ženy 2010/2011 a 2011/2012}

Hodnocení žen na akrobacii se v roce 2010/2011 oproti přijímacímu řízení v roce 2011/2011 zhoršilo. Toto zhoršení však nebylo statisticky významné. Důvodem může být zařazení zpevňovacích cvičení, které má prokázat schopnost ovládat tělo jako celek. I když tato cvičení vypadají na první pohled jednoduše, bez předchozího vysvětlení, nácviku a odborné korekce, mohlo řadě uchazečů přinést bodovou srážku. Dalším důvodem může být pro mnoho uchazečů nedostupná tělocvična s odborným vedením, tak, jak jsme se o tom zmiňovali výše.

\section{komparace výsledků akrobacie - ženy 2010/2011 a 2011/2012}

Výsledky hodnocení mužů se v přijímacím řízení pro rok 2011/2012 statisticky významně zhoršily. Důvodem může být, stejně jako u žen, zařazení zpevňovacích cvičení, př́ípadně nedostatečné materiální vybavení, odborné vedení nebo možná jen malá snaha uchazečů o př́ípravu.

\section{Výsledky analýzy vztahu mezi jednotlivými disciplínami}

Výsledky analýzy vztahu mezi jednotlivými disciplínami v přijímacím řízení v letech 2010/2011 a 2011/2012 uvádíme v tabulce 5 .

Tab. 5 Analýza vztahu mezi jednotlivými disciplinami v letech 2010/2011 a 2011/2012

\begin{tabular}{|c|c|c|c|c|c|c|c|c|}
\hline & $\begin{array}{c}\text { hrazda- } \\
\text { ženy- } \\
2010 \\
\end{array}$ & $\begin{array}{c}\text { hrazda- } \\
\text { ženy- } \\
2011 \\
\end{array}$ & $\begin{array}{c}\text { hrazda- } \\
\text { muži- } \\
\mathbf{2 0 1 0}\end{array}$ & $\begin{array}{c}\text { hrazda- } \\
\text { muži- } \\
2011 \\
\end{array}$ & $\begin{array}{l}\text { akrobacie- } \\
\text { ženy-2010 }\end{array}$ & $\begin{array}{l}\text { akrobacie- } \\
\text { ženy-2011 }\end{array}$ & $\begin{array}{l}\text { akrobacie- } \\
\text { muži-2010 }\end{array}$ & $\begin{array}{l}\text { akrobacie- } \\
\text { muži-2011 }\end{array}$ \\
\hline $\begin{array}{l}\text { hrazda- } \\
\text { ženy-2010 }\end{array}$ & 1 & ,9768 & & & ,9742 & ,9620 & & \\
\hline $\begin{array}{l}\text { hrazda- } \\
\text { ženy-2011 }\end{array}$ & ,9768 & 1 & & & ,9651 & ,9636 & & \\
\hline $\begin{array}{c}\text { hrazda- } \\
\text { muži-2010 }\end{array}$ & & & 1 & 9143 & & & 9041 & ,9550 \\
\hline $\begin{array}{c}\text { hrazda- } \\
\text { muži-2011 }\end{array}$ & & & ,9143 & 1 & & & ,9377 & ,9515 \\
\hline $\begin{array}{l}\text { akrobacie- } \\
\text { ženy-2010 }\end{array}$ & ,9742 & ,9651 & & & 1 & ,9718 & & \\
\hline $\begin{array}{l}\text { akrobacie- } \\
\text { ženy-2011 }\end{array}$ & ,9620 & ,9636 & & & ,9718 & 1 & & \\
\hline $\begin{array}{l}\text { akrobacie- } \\
\text { muži-2010 }\end{array}$ & & & ,9041 & 9377 & & & 1 & ,9387 \\
\hline $\begin{array}{l}\text { akrobacie- } \\
\text { muži-2011 }\end{array}$ & & & ,9550 & ,9515 & & & ,9387 & 1 \\
\hline
\end{tabular}

K hodnotě korelačního koeficientu sledujeme i jeho druhou mocninu, což je index determinace. Ten vysvětluje, z kolika procent je vztah vyjádřen našimi daty a z kolika procent je tvořen neznámými vlivy. Uvedené hodnoty (tab. 5) korelačních koeficientů jsou z tohoto pohledu vysoké a to mezi jednotlivými disciplínami 
a to jak mezi hrazdou dosažnou nebo doskočnou použitou v roce 2010/2011 a závěsnou hrazdou využitou v roce 2011/2012, ale také mezi hrazdami a akrobací́.

\section{Interpretace výsledků analýzy vztahu mezi jednotlivými disciplínami}

Vysoké hodnoty korelačních koeficientů nám ukazují na možnou zaměnitelnost jednotlivých disciplín. Tento nástroj nám může říct, že uchazeči dosahovali téměř shodných výsledků v obou disciplínách. Zjednodušeně se dá říci, že uchazeči, kteří získali vysoké bodové hodnocení na hrazdě, získali vysoké hodnocení také na akrobacii. To by mohlo ukazovat na připravenost jednotlivých uchazečů a vést $\mathrm{k}$ myšlence, že ti, kteří se připravovali, trénovali obě disciplíny.

\section{Závěr:}

V naší práci jsme se zaměřili na komparaci hodnocení gymnastických disciplín (závěsná hrazda x hrazda, akrobacie) v prrijímacím řízení v akademických letech 2010/2011 a 2011/2012 po změně obsahu jednotlivých disciplín.

Dalším cílem příspěvku bylo zjištění vztahu v hodnocení jednotlivých disciplín a jejich možné zaměnitelnosti v dalším přijímacím řízení.

Výsledky komparace jednotlivých disciplín ukázaly na skutečnost, že nahrazení doskočné (dosažné) hrazdy za hrazdu závěsnou výrazně pomohlo mužům v hodnocení této disciplíny. Naopak se ukázalo, že i přes mírný bodový pokles u žen po změně sestavy, přináší cvičení na akrobacii bodové zvýhodnění právě ženám.

Jak bylo zmíněno na úvod našeho př́spěvku, ve snaze co možná nejlépe postihnout úroveň motorických schopností a určitých pohybových předpokladů potřebných pro studium praktických předmětů s gymnastickým zaměřením a také v souladu s hledisky ekonomickými, neustále hledáme nejvhodnější nářadí a také jeho obsah pro přijímací řízení. Po zpracování analýzy vztahu mezi jednotlivými disciplínami jsme došli k závěru, že je možné jednotlivé disciplíny vzájemně zaměňovat. A vzhledem ke skutečnosti, že v posledních několika letech skoro trojnásobně převyšuje v oborech Trenérství a Animátor sportovních aktivit počet mužských uchazečů nad ženskými, rozhodli jsme se v letošním přijímacím řízení pro rok 2012/2013 ponechat jen sestavu na akrobacii, protože při cvičení na akrobacii dosahovaly ženy lepších výsledků. Obsah sestavy je shodný s obsahem přijímacích zkoušek pro rok 2011/2012. Toto opatření je pouze malou výhodou uchazečkám s ohledem na nutnost úspěšného splnění limitů přijímacího řízení také z jiných sportovních disciplín (atletika, basketbal, plavání, atd.).

Pro srovnání uvádíme jen dílčí výsledky hodnocení přijímacích zkoušek z gymnastiky pro akademický rok 2012/2013. Muži dosáhli v akrobacii průměrně 6,37 bodu a ženy 7,09 bodu.

\section{Literatura}

COHEN, J. The earth is round, $p<05$. American Psychologist, 49:997-1003. 1994.

HAVLÍČKOVÁ, L et al. Fyziologie tělesné zátěže II.: Speciální část - 1.díl. 1. Praha: Karolinum, 1993. 238 s. ISBN 80-7066-815-6.

HEDBÁVNÝ, P. Vliv úrovně rovnováhových schopností na provedení vybraných gymnastických pohybových struktu. Disertační práce. FSpS MU, Brno. 2011.

JALOVECKÁ, B. Vliv hodnotových orientaci na výkon ve sportovni gymnastice žen. Disertační práce. FSpS MU, Brno. 2010.

KUBIČKA, Jiří, et al. Vybrané kapitoly z teorie gymnastiky. 1. Praha: Karolinum, 1993. 49 s. ISBN 80-7066-721-4.

MRAČKOVÁ, E. Využití regeneračních prostředků ve sportovní gymnastice. Bakalářská práce. FSpS, MU, Brno. 2011.

VACUlÍKOVÁ, P., SKOTÁKOVÁ, A., SVOBODOVÁ, L., ŠIMBEROVÁ, D., HEDBÁVNÝ, P. Nebojme se gymnastiky... Textová opora ke kurzu. 1. vyd. Brno: Masarykova univerzita, 2011. 20 s. ISBN 978-80-210-5622-0.

VANĚK, M. et al. Psychologie sportu: Rozbor psychických složek sportovního výkonu. Praha: Olympia, 1984. 202 s. ISBN 27-010-84. 


\section{Př́lohy}

Obsah jednotlivých disciplín pro akademický rok 2010/2011

\section{Doskočná hrazda - muži}

Výmyk tahem ze svisu, zášvih - toč vzad - podmet

Dosažná hrazda po čelo - ženy

Ze shybu stojmo výmyk odrazem snožmo, zášvih - toč vzad - podmet

Akrobacie - ženy

Z rozběhu přemet vpřed, 2-3 kroky - váha předklonmo - vzpřim - výskokem celý obrat, stoj na rukou a kotoul, vztyk - cvalový poskok a dálkový skok, 2-3 kroky a přemet stranou do stoje rozkročného, přinožit, připražit.

\section{Akrobacie - muži}

Z rozběhu přemet vpřed - výskokem celý obrat, výkrokem váha předklonmo - vzpřim - stoj na rukou a kotoul, vztyk - z rozběhu přemetový poskok a přemet stranou do stoje rozkročného, přinožit a připažit - výskokem půlobrat - dřepem kotoul vzad do zášvihu - vzpřim - připažit.

\section{Obsah jednotlivých disciplín pro akademický rok 2011/2012}

\section{Závěsná hrazda - ženy}

Svis čelem k žebřinám - shyb, výdrž 5 sekund - svis (4 body), celý obrat vpřed do svisu zády k žebřinám ( 3 body), přednos s výdrží 3 sekund ( 3 body)

\section{Závěsná hrazda - muži}

Svis čelem k žebřinám - shyb $3 \mathrm{x}$ - svis (4 body), celý obrat vpřed do svisu zády k žebřinám (3 body), přednos výdrží 3 sekund ( 3 body)

\section{Akrobacie - ženy}

Přemetový poskok - přemet (2 body), poskokem vzpor dřepmo, odrazem vzpor ležmo, celým obratem vzpor ležmo vzadu, celým obratem vzpor ležmo (1 bod), odrazem vzpor dřepmo, výskokem s celým obratem stoj spatný, výkrokem stoj na rukou a kotoul - vztyk (2 body), výkrokem váha předklonmo, vzpřim (1 bod), cval - dálkový skok (1 bod), celý obrat jednonož (1 bod), přemetový poskok - přemet stranou (2 body)

\section{Akrobacie - muži}

Přemetový poskok - přemet (2 body), pádem klik - vzpor ležmo (1 bod), celým obratem vzpor ležmo vzadu, celým obratem vzpor ležmo (1 bod), odrazem vzpor dřepmo, výskokem s celým obratem stoj spojný, výkrokem stoj na rukou a kotoul - do dřepu (2 body), kotoul vzad do zášvihu, vztyk (1 bod), výkrokem váha předklonmo, vzpřim (1 bod), přemetový poskok - přemet stranou ( 2 body). 